\title{
Phytochemical Characterization of the Essential Oils Obtained from Mediterranean Thymus spp. (Lamiacea) Harvested at Different Stages of Growth
}

\author{
Aisha Touhami ${ }^{1,2}$, Azzedine Chefrour ${ }^{3}$, Nabila Khellaf ${ }^{1,4}$, Abbes Bukhari ${ }^{1,3,5}$ and Ismail Fadel ${ }^{1,4}$ \\ 1. Laboratory of Organic Synthesis-Modeling and Optimization of Chemical Processes, Badji Mokhtar University, Annaba 23000, \\ Algeria \\ 2. EPST-Annaba, Annaba 23000, Algeria \\ 3. Laboratory of Botany, Faculty of Natural Science and Life, Mohamed Cherif Messaadia University, Souk-Ahras 41000, Algeria \\ 4. Department of Process Engineering, Faculty of Engineering, Badji Mokhtar University, Annaba 23000, Algeria \\ 5. Department of Chemistry, Faculty of Science, Badji Mokhtar University, Annaba 23000, Algeria
}

\begin{abstract}
To prove more information on the chemical composition of the essential oils of Thymus taxa collected in different Algeria areas, and to determine the effect of harvesting periods on the composition of these essential oils: three Thymus species (T. numidicus, T.ciliatus and T. algeriensis) were collected during two periods of development, the EOs (essential oils) obtained by steam distillation of the aerial parts were analyzed by GC/MS (gas chromatography coupled with mass spectrometry). During the pre-flowering stage, the $R P \%$ (relative percentage) of Eos varied between $1.00 \%$ and $1.34 \%$ for all the species. The content of EOs increased during the flowering stage and reached particularly $2.10 \%$ and $2.85 \%$ for T. numidicus (from Berrahal) and T. numidicus (from Tacha), respectively. GC/MS analysis showed that these oils are very rich in oxygenated monoterpenes group $(76.96 \% \sim 82.11 \%)$ when the plants were harvested during the flowering stage of growth. Thymol was the major compound in the EOs contained in T. numidicus (Berrahal) and T. ciliatus with more than 39\% and 54\%, respectively. Thymus numidicus (Tacha) and T. algeriensis EOs were characterized by high content in p-cimene-7-ol (78.06\% and 26.98\%, respectively). These two chemotypes (thymol and p-cimene-7-ol) are considered as antioxidant and antimicrobial agents providing the basis for many applications in processed food preservation and pharmaceutical products.
\end{abstract}

Key words: Bioactive molecule, chemotype, T. algeriensis, T. ciliates, T. numidicus Benth.

\section{Introduction}

Thyme, a Lamiaceae aromatic plant, is a perennial medicinal species belonging to Europe, Africa and Asia including about approximately 110 species $[1,2]$. The different species are distributed along the cost and even in the intern and arid areas. In the North Africa countries (Algeria, Tunisia and Morocco), thyme leaves extracts, despite their frequent use as a spice and infusions, are used in traditional medicine as astringent, expectorant, antiseptic, antirheumatic, diuretic, analgesic and cicatrizing agents, as reported in

Corresponding author: Aisha Touhami, assistant professor, research field: photochemistry. several studies [1, 3-5]. Thyme can also be used as a veterinary product (antispasmodic, antiseptic and digestive); it is applied as feed additives and for treating diseases for pets and farm animals [6].

EOs (essential oils) contained in plants constitute a potential source of bioactive molecules $[7,8]$. In the opposite of lipids (fixed oils), EOs are volatile and odorous substances also called chemotypes because of the difference in quantity and quality of their compounds present in the same genus; this difference is related to genome or gene expression differences [9] and to some abiotic parameters, such as geographical origin, harvest time, temperature, storage conditions 
and drying time $[10,11]$. Particularly, EOs extracted from Thymus species are considered as the most active oils because of their high concentration in phenolic compounds (mainly thymol and carvacrol). Their antioxidant and antimicrobial properties provide the basis for many applications in raw and processed food preservation and pharmaceutical products [12]. Essential oils have been investigated in several studies where the scope was the chemical analysis of these compounds and their biological activities against several bacteria, yeast and fungi [7, 13, 14]. Research interests must continue to identify EO bioactive compounds present in Thymus species native to different parts of the world. Since plant EOs are generally affected by the geographical location and the phase of the plant development, the aim of the present work was to provide more information on (1) the chemical composition of EOs extracted from some Thymus species originated from different Algerian areas and (2) the effect of harvesting period on the composition of these EOs. For this purpose, three species largely abundant in these regions, Thymus numidicus, Thymus ciliatus and Thymus algeriensis were selected. They were collected before and during flowering stage of growth in four regions of Eastern Algeria.

\section{Materials and Methods}

\subsection{Plant Material and Chemical Reagents}

Three species of Thyme, T. numidicus, T. ciliatus and T. algeriensis were collected from different areas of Eastern Algeria. The species were identified by experts from Botany Laboratory, Badji Mokhtar University-Annaba. Plant material consisted of leaves and flowering tops was air-dried and kept under dark until constant weight. Table 1 summarizes the areas and dates of collection of thyme species with some geographical coordinates of the different regions. The dates of collection were selected according to pre-flowering (March or April) and flowering stages (May or June) of plant growth.

\subsection{Essential Oil Analysis}

The essential oils were obtained by hydrodistillation using a Clevenger-type apparatus according to the standard procedure. Approximately $50 \mathrm{~g}$ of dried plant were placed in a flask with $500 \mathrm{~mL}$ distilled water for $3 \mathrm{~h}$. Following distillation, the oils collected from the condenser were stocked in closed tubes and placed at $4{ }^{\circ} \mathrm{C}$ to ovoid oil alteration and oxidation.

The distillation was followed by determining the $R P \%$ (relative percentage) of EOs defined as the ratio between the EO mass $\left(M_{E O}\right)$ and the dry weight of the thyme material $\left(M_{T}\right)$; it was evaluated by the following relationship:

$$
R P \%=\frac{M_{E O}}{M_{T}} \times 100
$$

Oils analysis was carried out by GC-MS (gas chromatography coupled to mass spectrometry). The apparatus type SHIMAZU QP2010 with a FID detector was equipped with a capillary column $(25 \mathrm{~cm}$ long, $0.25 \mathrm{~mm}$ in diameter). The analysis conditions were as follows: helium at $1.7 \mathrm{~mL} / \mathrm{min}$ as gas carrier,

Table 1 Origin of Thymus species under study (Eastern Algeria).

\begin{tabular}{llll}
\hline Species name & Area of collection & Geographical Coordinates & Date of collection \\
\hline \multirow{2}{*}{ T. numidicus-B } & Berrahal-Annaba & $36^{\circ} 76^{\prime} 52^{\prime \prime} \mathrm{N}$ & March 2010 \\
& & $7^{\circ} 44^{\prime} 90^{\prime \prime} \mathrm{E}$ & May 2010 \\
T. numidicus-T & Tacha-Annaba & $36^{\circ} 88^{\prime} 97^{\prime \prime} \mathrm{N}$ & March 2010 \\
& & $7^{\circ} 37^{\prime} 79^{\prime \prime} \mathrm{E}$ & May 2010 \\
T. ciliatus & Ain Makhlouf-Guelma & $36^{\circ} 19^{\prime} 33^{\prime \prime} \mathrm{N}$ & April 2010 \\
& & $7^{\circ} 26^{\prime} 49^{\prime \prime} \mathrm{E}$ & June 2010 \\
T. algeriensis & Selaoua Anouna-Guelma & $36^{\circ} 36^{\prime} 66^{\prime \prime} \mathrm{N}$ & April 2010 \\
& & $7^{\circ} 31^{\prime} 66^{\prime \prime} \mathrm{E}$ & June 2010 \\
\hline
\end{tabular}


the injection volume was $0.1 \mathrm{~mL}$ and the ionization potential was $70 \mathrm{eV}$. The column temperature was fixed at $60{ }^{\circ} \mathrm{C}$ during $1 \mathrm{~min}$ then increased until $200{ }^{\circ} \mathrm{C}$ with a rate of $3{ }^{\circ} \mathrm{C} / \mathrm{min}$ and finally maintained at this temperature during $16 \mathrm{~min}$.

This technique is based on the measure of retention time which is specific to each compound present in oil. The compounds were identified by comparison of their mass spectra with those contained in the NIST bookshop.

\section{Results and Discussion}

\subsection{Thymus Species Content in EOs}

The different EOs obtained from the four Thymus species had a light yellow color. The $R P \%$ of these EOs were measured and reported in Table 2 which shows that during the pre-flowering stage, the $R P \%$ varied between $1.00 \%$ and $1.34 \%$ for all the species. The content of EOs increased during the flowering stage and reached $2.10 \%$ and $2.85 \%$ for T. numidicus-B and T. numidicus-T, respectively, showing that this thyme species is richer in EOs than the two others. Conversely in a similar study, Amrouni et al. [7] reported a slight higher relative percentage (3\%) of EOs present in the oils of T. ciliatus collected from another Eastern region not far from Berrahal and Tacha (Djebel El Edough-Annaba). However, Hadef et al. [15] found lower percentages of EOs in T. numidicus originated from Lakhdaria, a region in center Algeria. A same relative percentage of EOs present in T. algeriensis (from Algeria) was obtained by Dob et al. [13] with $1.13 \%$. Generally, the results found in our present study are very similar to those reported in literature with some few exceptions probably dues to some ecological and climatic conditions (temperature, location, soil type and harvest time) and some laboratory operating conditions (drying time, extraction and analytical techniques) [3].

\subsection{Chemical Composition of EOs}

GC-MS analysis of the four plants EOs provided the different compounds present in these oils. Thymus species are very variable in the essential oil composition. The quantity of each compound is also variable and this is related to various environmental and genetic factors [2]. The four extracted oils contained 43, 12, 52 and 19 compounds in the EOs of T. numidicus-B, T. numidicus-T, T. ciliatus and T. algeriensis, respectively (Table 3 ). The two species T. numidicus-B and T. ciliatus are very rich in thymol, carvacrol and terpinene which are considered as antimicrobial agents [16]. Thymol was the major compound of the EOs contained in T. numidicus-B and T. ciliatus with more than $39 \%$ and $54 \%$, respectively. According to the chemical characterization of the same species (from the same regions), Giordani et al. [17] reported $66.31 \%$ and $60.52 \%$ of thymol in the extracted oils. The difference with our results may be due to some abiotic parameters not reported in the study, such as temperature and drying time. Several studies on the chemical characterization of Thyme species originated from different regions of the world (Algeria, Iran, Morocco, Turkey) have been conducted and have shown that thymol was the predominant compound in the EOs of plants [15, 18-21]. According to Nezhadali et al. [22], the high content of medicinal plants in thymol means that these plants could be used as flavoring agents in food, medicinal and perfume

Table 2 Relative percentage of EOs contained in Thymus species under study.

\begin{tabular}{lll}
\hline \multirow{2}{*}{ Species } & \multicolumn{1}{c}{$R P \%$} \\
\cline { 2 - 3 } & Pre-flowering stage & Flowering stage \\
\hline$T$. numidicus-B & 1.28 & 2.85 \\
$T$. numidicus-T & 1.34 & 2.10 \\
$T$. ciliatus & 1.00 & 1.79 \\
$T$. algeriensis & 1.16 & 1.77 \\
\hline
\end{tabular}


(Lamiacea) Harvested at Different Stages of Growth

Table 3 Chemical composition (\%) of Thymus EOs (flowering stage).

\begin{tabular}{|c|c|c|c|c|}
\hline Compounds * & T. numidicus-B & T. numidicus-T & T. ciliatus & T. algeriensis \\
\hline \multicolumn{5}{|c|}{ Monoterpene hydrocarbons } \\
\hline$\alpha$-thujene & 0.18 & - & 0.14 & - \\
\hline$\alpha$-pinene & 0.57 & 1.93 & 0.46 & 3.08 \\
\hline Camphene & 0.04 & - & - & - \\
\hline Myrcene & 1.28 & 0.99 & 1.55 & - \\
\hline$\alpha$-phyllandrene & 0.26 & - & - & - \\
\hline$\beta$-cymene & 6.54 & 5.73 & 5.96 & 7.74 \\
\hline Limonene & 0.10 & 0.43 & 0.48 & - \\
\hline O-cimene & - & - & 0.04 & - \\
\hline Trans $\beta$-ocimene & 0.26 & - & 0.41 & - \\
\hline Cis $\beta$-cymene & 0.40 & - & 0.65 & - \\
\hline$\gamma$-terpinene & 6.12 & 6.88 & 4.75 & 5.64 \\
\hline Terpinolene & 0.17 & - & 0.20 & - \\
\hline 2-carene & 0.65 & - & 0.60 & - \\
\hline 4-carene & 0.01 & 0.98 & 0.00 & - \\
\hline Dimethyl styrene & 0.32 & - & 0.28 & - \\
\hline \multicolumn{5}{|c|}{ Oxygenated monoterpenes } \\
\hline Eucalyptol & 1.88 & - & 2.34 & 2.01 \\
\hline Linalool & 7.47 & 0.73 & 8.55 & 2.60 \\
\hline Pinocarveol & 0.05 & - & - & 2.67 \\
\hline Camphor & 1.29 & - & 3.28 & 3.64 \\
\hline Borneol & 0.94 & - & 0.75 & - \\
\hline Isoborneol & - & - & - & 2.28 \\
\hline Terpinen-4-ol & 1.90 & 0.57 & 0.96 & - \\
\hline$\gamma$-terpineol & 0.10 & - & 0.23 & - \\
\hline Thymol & 39.66 & - & 54.04 & - \\
\hline Carvacrol & 23.52 & - & 7.09 & - \\
\hline Pinen-10-ol & - & - & 0.23 & - \\
\hline Cis-pinen-3-ol & - & - & 0.58 & - \\
\hline Trans-3-carene-2-ol & - & - & 0.42 & - \\
\hline Pinen-3-one & - & - & 0.14 & - \\
\hline Verbenone & 0.05 & - & 0.13 & 13.18 \\
\hline Thujenal & - & - & 0.14 & - \\
\hline Isothujol & - & - & 0.09 & 1.08 \\
\hline Carveol & - & - & 0.14 & - \\
\hline Thymol-methyl-ether & - & - & 1.00 & - \\
\hline Caprique aldehyde & - & - & - & 0,96 \\
\hline Trans-linalool oxyde & 0.07 & - & - & - \\
\hline Cis-linalool oxyde & - & - & 0.19 & - \\
\hline$\gamma$-terpineol acetate & - & - & 0.05 & - \\
\hline P-cimene-7-ol & - & 78.06 & - & 26.98 \\
\hline Vinyl format & - & 0.16 & - & - \\
\hline Bergamol & - & - & - & 1.7 \\
\hline Carveol dihydro & - & - & - & 0.83 \\
\hline Methyl ter buthy ether & - & 2.59 & - & 19.63 \\
\hline Caproique aldehyde & - & - & 0.02 & - \\
\hline Caprylic alcohol & 0.03 & - & - & - \\
\hline
\end{tabular}


(Table 3 continued)

\begin{tabular}{|c|c|c|c|c|}
\hline Compounds * & T. numidicus-B & T. numidicus-T & T. ciliatus & T. algeriensis \\
\hline \multicolumn{5}{|c|}{ Sesquiterpene hydrocarbons } \\
\hline$\alpha$-cubebene & 0.02 & - & - & - \\
\hline y-langene & 0.05 & - & - & - \\
\hline Copaene & 0.13 & - & 0.04 & - \\
\hline Caryophyllene & 0.26 & - & 0.38 & - \\
\hline Humulene & 0.17 & - & - & - \\
\hline$\gamma$-murolene & 0.43 & - & 0.11 & - \\
\hline D-germacrene & 0.21 & - & 0.19 & - \\
\hline$\alpha$-farnesene & - & - & 0.08 & - \\
\hline$\beta$-farnesene & - & - & 0.34 & - \\
\hline$\gamma$-cadinene & 0.65 & - & 0.26 & - \\
\hline Bisabolene & 0.16 & - & - & - \\
\hline$\alpha$-amorphene & 0.02 & - & - & - \\
\hline Bourbonene & 0.15 & - & 0.06 & - \\
\hline Aristolene & 0.14 & - & - & - \\
\hline Fenchene & - & - & 0.12 & - \\
\hline Aromadendrene & 0.05 & - & - & - \\
\hline Bergamotene & - & - & 0.02 & - \\
\hline \multicolumn{5}{|l|}{ Oxygenated sesquiterpenes } \\
\hline Mertenyl acetate & 0.04 & - & 0.04 & 2.59 \\
\hline$\alpha$-trans-bisabolene epoxyde & 0.03 & - & 0.05 & 1.44 \\
\hline$\alpha$-tetradecine & - & - & 0.06 & - \\
\hline$\alpha$-dodecylene & - & - & 0.07 & - \\
\hline Vinyl amyl carbinol & 3.37 & 0.95 & 2.03 & 1.12 \\
\hline Citroviol & 0.26 & - & - & - \\
\hline Isovaleral & - & - & - & 0.83 \\
\hline Longipinene epoxyde & - & - & 0.03 & - \\
\hline Ascaridol epoxyde & - & - & 0.07 & - \\
\hline Mercenyl acetate & - & - & 0.03 & - \\
\hline 3-decene-2-ol & - & - & 0.02 & - \\
\hline Eugol acetate & - & - & 0.11 & - \\
\hline
\end{tabular}

“-”: Compound not identified.

industries. In addition, this monoterpene phenol possesses different biological and pharmacological properties, such as antimutagenic, antitumor, antioxidant and anti-inflammatory [16].

The major constituent in the oils of T. numidicus-T and $T$. algeriensis was p-cimene-7-ol; it was concentrated at more than $78 \%$ and $26.98 \%$, respectively. The predominant compound in thyme plants differ from species to another and from an area to another. Ballester-Costa et al. [12] characterized four Mediterranean Thymus species (T. vulgaris, $T$. zygis, T. mastichina and T. capitatus) originated from
Spain; the authors found that the major compound in the different oils was respectively 1,8-cineole (51.94\%), thymol (48.59\%), carvacrol (69.83\%) and linaool (44.00\%). A Moroccan Thymus species (T. maroccanus) was analyzed for its EOs at different developmental stages; the analysis by GC/MS revealed the presence of 28 components with $14.1 \% \sim 77.6 \%$ of carvacrol as major compound [4].

Essential oils extracted from plants consist of chemical compounds groups known as monoterpenes, sesquiterpenes and their oxygenated and hydrocarbons derivatives. These compounds have the ability to easily 
diffuse across cell membrane to induce biological reactions [23]. The most represented chemical groups in the four species selected in the present study are oxygenated monoterpenes (phenolics compounds) with $76.96 \% \sim 82.11 \%$; the monoterpene hydrocarbons were present with approximately $26 \%$ in the four species. The two other groups (sesquiterpene hydrocarbons and oxygenated sesquiterpenes) were present at very low percentage (Fig. 1). It has been demonstrated that the anti-microbial activity of most essential oils is related to their phenolic monoterpenes [24-26].

\subsection{Effect of Growth Stage on the Chemical Composition of Thymus EOs}

Identified compounds in the Thymus EOs were different in number and percentage of the chemical groups during flowering and pre-flowering stages of plant growth (Table 4). Studies on some Thymus species indicated that in the plant's life cycle, the oil production is usually at its highest level during the flowering period [3]. This is in agreement with our results which show that plants harvested during the flowering stage contained more concentrated compounds. Particularly, the $R P \%$ of oxygenated monoterpens (and oxygenated sesquiterpenes) was higher than that of the pre-flowering stage and attained $(76.96 \% \sim 82.11 \%)(0.95 \% \sim 5.98 \%)$ for the four species. Consequently, the monoterpenes hydrocarbons and sesquiterpene hydrocarbons concentration decreased. This may be due to an increasing in photosynthetic activity which induces a high rate of biosynthesis of volatile compounds (mainly the phenolic compounds) at full flowering stage [4].

Some monoterpenes constituents (cymene, $\gamma$-terpinene, carvacrol and p-cimene-7-ol) were absent (or present at very low concentrations) in the different EOs when the plants were harvested before flowering (Table 5). Their concentration increased significantly during the flowering stage of growth mainly

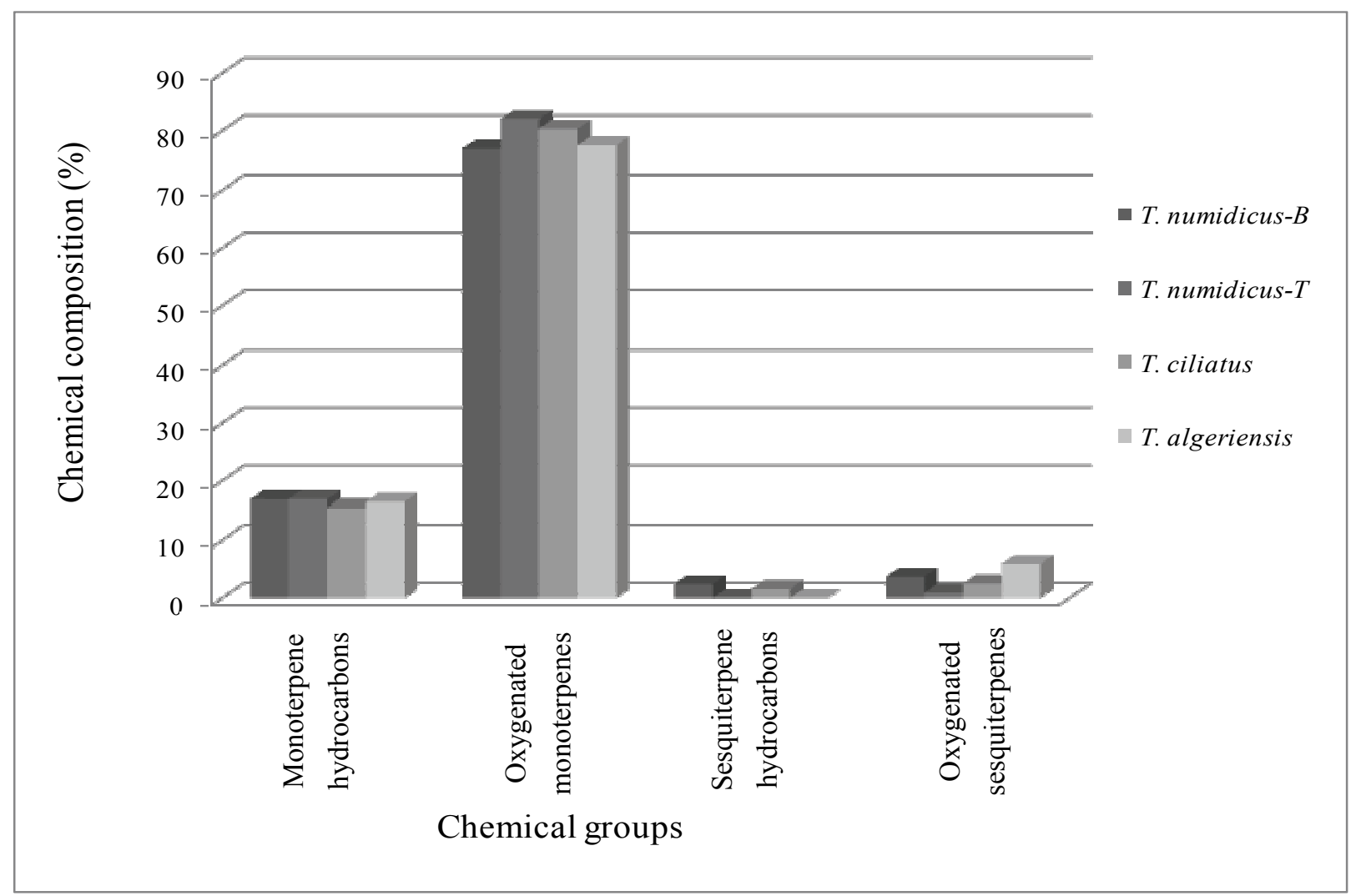

Fig. 1 Chemical composition of the different chemical groups present in Thymus EOs. 
Table 4 Number of compounds and relative percentage of EOs (\%) contained in Thymus species harvested during flowering stage and pre-flowering stage of plant growth.

\begin{tabular}{lllllll}
\hline \multirow{2}{*}{ Species } & & $\begin{array}{l}\text { Number of } \\
\text { Compounds }\end{array}$ & $\begin{array}{l}\text { Monoterpene } \\
\text { Hydrocarbons }\end{array}$ & $\begin{array}{l}\text { Oxygenated } \\
\text { monoterpenes }\end{array}$ & $\begin{array}{l}\text { Sesquiterpene } \\
\text { Hydrocarbons }\end{array}$ & $\begin{array}{l}\text { Oxygenated } \\
\text { sesquiterpenes }\end{array}$ \\
\hline \multirow{2}{*}{ T. numidicus-B } & Pre-flowering stage & 24 & 38.23 & 54.48 & 6.09 & 1.20 \\
\cline { 2 - 7 } & Flowering stage & 43 & 16.9 & 76.96 & 2.44 & 3.70 \\
\hline \multirow{2}{*}{ T. numidicus-T } & Pre-flowering stage & 14 & 31.18 & 67.20 & 1.13 & 0.49 \\
\cline { 2 - 7 } T. ciliatus & Flowering stage & 12 & 16.94 & 82.11 & 0.00 & 0.95 \\
\hline \multirow{2}{*}{ T. algeriensis } & Pre-flowering stage & 13 & 35.8 & 54.07 & 10.13 & 0.00 \\
\cline { 2 - 7 } & Flowering stage & 52 & 15.52 & 80.37 & 1.6 & 2.51 \\
\hline & Pre-flowering stage & 30 & 25.36 & 61.86 & 10.68 & 2.10 \\
\hline
\end{tabular}

Table 5 Chemical composition (\%) of Thymus EOs extracted from plants during flowering stage (in bold) and pre-flowering stage (in normal) of growth.

\begin{tabular}{|c|c|c|c|c|c|}
\hline Compounds* & & T. numidicus-B & T. numidicus-T & T. ciliatus & T. algeriensis \\
\hline \multirow{2}{*}{$\beta$-cymene } & Pre-flowering stage & - & - & - & - \\
\hline & Flowering stage & 6.54 & 5.73 & 5.96 & 7.74 \\
\hline \multirow{2}{*}{ Limonene } & Pre-flowering stage & - & - & - & 5.13 \\
\hline & Flowering stage & 0.10 & 0.43 & 0.48 & - \\
\hline \multirow{2}{*}{ Isolimonene } & Pre-flowering stage & - & - & - & 5.5 \\
\hline & Flowering stage & - & - & - & - \\
\hline \multirow{2}{*}{ (E) $\beta$-ocimene } & Pre-flowering stage & 8.80 & - & - & - \\
\hline & Flowering stage & 0.26 & - & 0.41 & - \\
\hline \multirow{2}{*}{ O-cymene } & Pre-flowering stage & 22.35 & 23.14 & 11.88 & 6.36 \\
\hline & Flowering stage & - & - & - & - \\
\hline \multirow{2}{*}{$\gamma$-terpinene } & Pre-flowering stage & 0.16 & 5.06 & 22.34 & - \\
\hline & Flowering stage & 6.12 & 6.88 & 4.75 & 5.64 \\
\hline \multirow{2}{*}{ Terpinolene } & Pre-flowering stage & 4.33 & - & - & - \\
\hline & Flowering stage & 0.17 & - & 0.20 & - \\
\hline \multirow{2}{*}{ Eucalyptol } & Pre-flowering stage & - & - & - & 5.31 \\
\hline & Flowering stage & 1.88 & - & 2.34 & 2.01 \\
\hline \multirow{2}{*}{ Linalool } & Pre-flowering stage & 31.14 & 13.01 & 23.58 & 4.68 \\
\hline & Flowering stage & 7.47 & 0.73 & 8.55 & 2.6 \\
\hline \multirow{2}{*}{ Camphor } & Pre-flowering stage & - & - & - & 33.30 \\
\hline & Flowering stage & 1.29 & - & 3.28 & 3.64 \\
\hline \multirow{2}{*}{ Thymol } & Pre-flowering stage & 20.28 & 51.20 & 25.08 & - \\
\hline & Flowering stage & 39.66 & - & 54.04 & - \\
\hline \multirow{2}{*}{ Carvacrol } & Pre-flowering stage & - & - & - & - \\
\hline & Flowering stage & 23.52 & - & 7.09 & - \\
\hline \multirow{2}{*}{ Verbenone } & Pre-flowering stage & - & - & - & - \\
\hline & Flowering stage & 0.05 & - & 0.13 & 13.18 \\
\hline \multirow{2}{*}{$\begin{array}{l}\text { Thymol methyl } \\
\text { ether }\end{array}$} & Pre-flowering stage & - & - & 5.41 & - \\
\hline & Flowering stage & - & - & 1.00 & - \\
\hline \multirow{2}{*}{ p-cimene-7-ol } & Pre-flowering stage & - & - & - & - \\
\hline & Flowering stage & - & 78.06 & - & 26.98 \\
\hline \multirow{2}{*}{$\begin{array}{l}\text { Methyl ter } \\
\text { buthyl ether }\end{array}$} & Pre-flowering stage & - & - & - & - \\
\hline & Flowering stage & - & 2.59 & - & 19.63 \\
\hline
\end{tabular}

* The reported compounds are those with composition $\geq 5 \%$. 
for T. numidicus-T whose oil was very rich in p-cimene-7-ol (78.06\%). The flowering period can be profitable for extracting plant EOs and isolating these chemotypes for their use in food, cosmetic and perfumery industries [27]. For thymol, the concentration was variable in $T$. numidicus-B and $T$. ciliatus at the two different stages of growth. The values decreased from $39.66 \%$ and $54.04 \%$ (during flowering stage) to respectively $20.28 \%$ and $25.08 \%$ in EOs when the plants were harvested during the pre-flowering stage. Only O-cimene (and linalool) was present in plants during pre-flowering stage and was not detected (was detected at low concentrations) in Thymus species when harvested in their second stage of growth. A camphor-rich chemotype distinguished the oil of $T$. algeriensis from all other oils. The high content of $T$. algeriensis oil (33.30\%) suggests great potentialities of this species for industrial exploration, mainly as an antifungal and anti-inflammatory agent [28]. Additionally, in their study on the antioxidant capacity of some Lamiaceae species, Khled Khoudja et al. [29] confirmed that T. algeriensis containing high phenolic compounds showed a strong ability to act as an antioxidant agent.

\section{Conclusions and Perspectives}

The highest essential oil content was observed at flowering stage of growth in the four Thymus species originated from Eastern Algeria. The high thymol content of $T$. numidicus-B, T. numidicus-T and $T$. ciliatus and the high concentration of camphor in $T$. algeriensis make these four species promising bioressources for use in pharmaceutical, cosmetic and food industrial applications.

This first part of our work encourages further investigation for testing the extracted EOs from the four Thymus species for a bioactivity evaluation such as antimicrobial and antioxidant activities. Research may then continue to investigate a microbiological study in order to suggest new therapeutic applications with these Mediterranean plants.

\section{References}

[1] Chemat, S., Cherfouh, R., Meklati, B. Y., and Belanteur, K. 2012. "Composition and Microbial Activity of Thyme (Thymus algeriensis genuinus) Essential Oil.” J. Essent. Oil Res. 24 (1): 5-11.

[2] Llorens, L., Llorens-Molina, J. A., Agnello, S., and Boira, H. 2014. "Geographical and Environment-Related Variations of Essential Oils in Isolated Populations of Thymus richardii Pers. in the Mediterranean Basin." Biochem. Syst. Ecol. 56: 246-54.

[3] Gavahian, M., Farahnaky, A., Javidnia, K., and Majzoobi, M. 2012. "Comparison of Ohmic-Assisted Hydrodistillation with Traditional Hydrodistillation for the Extraction of Essential Oils from Thymus vulgaris L." Innovative Food Sci. Emerg. Technol. 14: 85-91.

[4] Jamali, C. A., Kasrati, A., Bekkouche, K., Hassani, L., Wohlmuth, H., Leach, D., and Abbad, A. 2013. "Phenological Changes to the Chemical Composition and Biological Activity of the Essential Oil from Moroccan Endemic Thyme (Thymus maroccanus Ball)." Ind. Crops Prod. 49: 366-72.

[5] Nikolic, M., Glamoclija, J., Ferreira, I. C. F. R., Calhelha, R. C., Fernandes, A., Markovic, T., et al. 2014. "Chemical Composition, Antimicrobial, Antioxidant and Antitumor Activity of Thymus serpyllum L., Thymus algeriensis Boiss. and Reut and Thymus vulgaris L. essential oils." Ind. Crops Prod. 52: 183-90.

[6] Baser, K. H. C., and Gerhard, B. 2010. Handbook of Essential Oils: Science, Technology and Applications. Abingdon: Francis \& Taylor Group, CRC Press.

[7] Amrouni, S., Touati, M., Hadef, Y., and Djahoud, A. 2014. "Effet de l'huile essentielle d'Origanum vulgare et de Thymus ciliatus sur Pseudomonas aeruginosa VIM-2 carbapénèmase." Phytothérapie 12: 309.

[8] Sadou, N., Seridi, R., Djahoudi, A., and Hadef, Y. 2015. "Composition chimique et activité antibactérienne des Huiles Essentielles des aiguilles de Pinus halepensis Mill. du nord est algérien." Rev. Sci. Technol. Synthèse 30: 33-9.

[9] Rodríguez-Solana, R., Daferera, D. J., Mitsi, C., Trigas, P., Polissiou, M., and Tarantilis, P. A. 2014. "Comparative Chemotype Determination of Lamiaceae Plants by Means of GC-MS, FT-IR, and Dispersive-Raman Spectroscopic Techniques and GC-FID Quantification.” Ind. Crops Prod. 62: 22-33.

[10] Verma, R. S., Padalia, R. C., and Chauhan, A. 2014. "Geographical Impact on Essential Oil Composition of Limnophila rugosa (Roth.) Merr.” J. Essent. Oil Res. 26 (5): 338-41.

[11] Kazemi, M., and Rostami, H. 2015. "Chemical Composition and Biological Activities of Iranian Achillea 
wilhelmsii L. Essential Oil: A High Effectiveness against Candida spp. and Escherichia Strains." Nat. Prod. Res. 29 (3): 286-9.

[12] Ballester-Costa, C., Sendra, E., Fernández-López, J., Pérez-Álvarez, J. A., and Viuda-Martos, M. 2013. "Chemical Composition and In Vitro Antibacterial Properties of Essential Oils of Four Thymus Species from Organic Growth." Ind. Crops Prod. 50: 304-11.

[13] Dob, T., Darhmane, D., Benabdelkader, T., Chelghoum, T. C. 2006. "Studies on the Essential Oils and Antimicrobial Activity of Thymus algeriensis Boiss. \& Reut." Inter. J. Aromatherapy 16 (2): 95-100.

[14] Pinto, E., Gonçalves, M. J., Oliveira, P., Coelho, J., Cavaleiro, C., and Salgueiro, L. 2014. "Activity of Thymus caespititius Essential Oil and $\alpha$-terpineol against Yeasts and Filamentous Fungi." Ind. Crops Prod. 26: 107-12.

[15] Hadef, H., Kaloustian, J., Chefrour, A., Mikail, C., Abou, L., Giodani, R., et al. 2007. "Chemical Composition and Variability of the Essential Oil of Thymus numidicus Poir. from Algeria." Acta Botan. Gallica: Bot. Letters 154 (2): 265-74.

[16] Nabavi, S. M., Marchese, A., Izadi, M., Curti, V., Daglia, M., and Nabavi, S. F. 2015. "Plants Belonging to the Genus Thymus as Antibacterial Agents: From Farm to Pharmacy." Food Chem. 173: 339-47.

[17] Giordani, R., Hadef, Y., and Kaloustian, J. 2008. "Compositions and Antifungal Activities of Essential Oils of Some Algerian Aromatic Plants." Fitoterapia 79: 199-203.

[18] Kabouche, Z., Boutaghane, N., Laggoune, S., Kabouche, A., Ait-Kaki, Z., and Benlabed, K. 2005. "Comparative Antibacterial Activity of Five Lamiaceae Essential Oils from Algeria." Int. J. Aromather. 15: 129-33.

[19] Hazzit, M., Baaliouamer, A., Verỉssimo, A. R., Faleiro, M. L., and Miguel, M. G. 2009. "Chemical Composition and Biological Activities of Algerian Thymus Oils." Food Chem. 116: 714-21.

[20] Saad, A., Fadli, M., Bouaziz, M., Benharref, A., Mezrioui, N. E., and Hassani, L. 2010. "Anticandidal Activity of the Essential Oils of Thymus maroccanus and Thymus broussonetii and Their Synergism with Amphotericin B and Fluconazol." Phytomedicine 17: 1057-60.
[21] Karaman, S., Digrak, M., Ravid, U., and Llcim, A. 2001. "Antibacterial and Antifungal Activity of the Essential Oils of Thymus revolutus Celak from Turkey." $J$. Ethnopharmacol. 76: 183-6.

[22] Nezhadali, A., Nabavi, M., Rajabian, M., Akbarpour, M., Pourali, P., and Amin, F. 2014. "Chemical Variation of Leaf Essential Oil at Different Stages of Plant Growth and In Vitro Antibacterial Activity of Thymus vulgaris Lamiaceae, from Iran.” Beni-suef Univ. J. Basic App. Sci. 3: 87-92.

[23] Naveed, R., Hussain, I., Tawab, A., Tariq, M., Rahman, M., Hameed, S., et al. 2013. "Antimicrobial Activity of the Bioactive Components of Essential Oils from Pakistani Spices against Salmonella and Other Multi-drug Resistant Bacteria." BMC Complem. Alter Med. 265: 13-4.

[24] Dehkordi, S. S., Tajik, H., Moradi, M., and Sigaroodi, F. K. 2010. "Chemical Composition of Essential Oils in Zataria multiflora Boiss. from Different Parts of Iran and Their Radical Scavenging and Antimicrobial Activity." Food Chem. Toxicol. 48: 1562-7.

[25] Sajed, H., Sahebkar, A., and Iranshahi, M. 2013. Zataria multiflora Boiss. (Shirazi thyme)—An Ancient Condiment with Modern Pharmaceutical Uses.” J. Ethnopharmacol. 145 (3): 686-98.

[26] El Asbahani, A., Jilele, A., Voisin, S. N., Aït Addi, E., Casabianca, H., El Mousadik, A., et al. 2015. "Chemical Composition and Antimicrobial Activity of Nine Essential Oils Obtained by Steam Distillation of Plants from the Souss-Massa Region (Morocco).” J. Essent. Oil Res. 27: 34-44.

[27] Ghanbarian, G. A., Naseri, M., Hatami, A., and Jafari, E. 2015. "Comparative Essential Oil Composition of Aerial Parts of Tanacetum dumosum Boiss. from Southern Zagros, Iran." Nat. Prod. Res. 29 (2): 197-200.

[28] Zuzarte, M., Gonçalves, M. J., Cavaleiro, C., Cruz, M. T., Benzarti, A., Marongiu, B., et al. 2013. "Antifungal and Anti-inflammatory Potential of Lavandula stoechas and Thymus herba-barona Essential Oils." Ind. Crops Prod. 44: 97-103.

[29] Khled Khoudja, N., Boulekbache-Makhlouf, L., and Madani, K. 2014. "Antioxidant Capacity of Crude Extracts and Their Solvent Fractions of Selected Algerian Lamiaceae." Ind. Crops Prod. 52: 177-82. 